\title{
An Exploration of the Problems of Du Fu's Spirit of Benevolence in the Cultural Construction of Military Academies
}

\author{
Jin Zhou ${ }^{1, \text { a }}$ \\ ${ }^{1}$ Officers College of PAP, Chengdu, 610213, China \\ aEmail: 437040854@qq.com
}

\begin{abstract}
Among the many cultural celebrities of Bashu, Du Fu has been mentioned in many courses of military academies. In military academies that emphasize "teaching for war" and "promoting war through learning," the problems, dissemination, and value of Du Fu's spirit of benevolence and cultural phenomena in the cultural construction of military academies are a topic worthy of in-depth study. This article will explore the problems of the cultural construction of Du Fu's benevolent spirit in military academies from three levels: the lack of communication hardware construction, the unity and lag of communication methods, and the flattening of dissemination content.
\end{abstract}

Keywords: Du Fu's spirit of benevolence, Hardware construction, Communication methods, Dissemination content.

\section{Introduction}

$\mathrm{Du} \mathrm{Fu}$ is the leading figure of Sheng Tang poetry and one of the most distinctive cultural celebrities in Bashu culture. Du Fu's spirit of benevolence has become a unique cultural phenomenon in the history of Chinese literature, and his personality has distinct characteristics and is highly recognizable in contemporary campuses. In military academies, the main channel for the appreciation of Du Fu's poetry and the dissemination of the spirit of benevolence was classroom instruction; Cadets can objectively understand the value and role of Du Fu's poetry and the spirit of benevolence in the cultural field and even in military careers, but they have different opinions on measuring the influence of it in military academies and military personnel. With the results of the questionnaire survey results, this article will analyze the problems about the spirit of benevolence implicated in $\mathrm{Du} F u$ and his deeds that existing in the construction of the campus culture of military academies.

\section{The Lack of Hardware Construction for Cultural Dissemination}

The dissemination of Du Fu culture formed by Du Fu's work and the spirit of benevolence contained in it is not the main aspect of the campus culture construction of military academies, and the campus culture propaganda here mainly refers to the cultural construction content that exists in physical form and can be perceived by people in the campus culture. Specific to the cultural dissemination of Du Fu's benevolent spirit, this lack of hardware construction is mainly manifested in the following aspects.

Among the cultural celebrities, Du Fu and his work are absent. A military academy stationed in Sichuan shows the effect of cultural celebrity in material forms such as posting celebrity portraits, erecting celebrity statues, and carving celebrity quotes.

First, the posterization of celebrity portraits is divided into two categories, one is to show Chinese and foreign celebrities who have outstanding contributions of science and engineering, such as Mendeleev, who discovered the periodic table of chemical elements, Chinese railway engineering expert Zhan Tianyou, etc.; the other is outstanding figures with major contributions inside and outside the military, such as the ten heroes of the August 1st Medal, and the faculty and staff who have made outstanding contributions to the construction of the army and even the academy.

Second, celebrity statues are divided into two categories, one is the statue of the ten loyal guards of the armed police, which is erected on the main road of the campus, reflecting a strong "military flavor"; the other is the statue of cultural celebrities, erected next to the boulevard, there are "three $\mathrm{Su}^{\text {", }}$ Lu Xun and so on.

Third, the carving of famous quotes is in large-scale texts such as "Listening to the party's command can win battles and have a good work style" that embody the characteristics of the troops; the other is famous sayings of cultural celebrities, such as the pre-Qin Zhuzi, the Eight Great Masters of the Tang and Song Dynasties, and foreign cultural celebrities.

Among these three types, Du Fu and his deeds are in a state of absence, and there is no publicity and dissemination of his spirit of concern for the country and the people and benevolence. The construction of military campus culture is mainly based on the embodiment of "military flavor", so the "quota" allocated to cultural celebrities is very small, let alone require military academies to be systematic in accordance with the cultural development system, even in ordinary colleges and universities can not comprehensively show the important cultural celebrities in traditional Chinese culture, so the lack of $\mathrm{Du} \mathrm{Fu}$ culture is also reasonable

\section{The Unity and Lag of Cultural Communication Methods}

Military academies and universities have always attached importance to political, ideological, and cultural construction, and cultural dissemination is one of the main ways for political, ideological, and cultural construction. The ideological and cultural construction of military academies is the main task of serving preparations for war, especially under 
the guidance of the military education policy in the new era, upholding the party's absolute leadership over the army, serving the rejuvenation of the army in a strong country, cultivating people with moral integrity, educating people for war, and cultivating high-quality and specialized new-type military talents with both political integrity and ability. This military education policy has also set higher demands on the cultural construction of military academies However, the cultural dissemination method of military schools shows unity and lag, which is mainly reflected in the following aspects. First, the traditional culture propaganda front, the blackboard newspaper display of $\mathrm{Du} \mathrm{Fu}$ and his work is low. Military academies retain the tradition of blackboard newspapers, and many cadets with graphic design talents can exert their personal strengths in this field and enrich the cultural construction of military school campuses. The propaganda of Du Fu's spirit of benevolence can occasionally appear in the blackboard newspaper with traditional Chinese culture as the theme, in addition, it is generally mainly to publicize new policies and new systems, and it is almost difficult to find Du Fu in the blackboard newspaper organized on major festivals such as July 1st, August 1st, National Day and other occasions. Second, the posters of conventional cultural propaganda exhibition boards also lack publicity for $\mathrm{Du}$ Fu's work and the spirit of benevolence. Most of the propaganda themes of the posters on the exhibition board revolve around the ideological and political theme education among the whole army, such as "inheriting the red gene and shouldering the heavy responsibility of strengthening the army".

Third, the dissemination way of Du Fu's spirit of benevolence is simple, mainly relying on the teaching content in related courses to expand its influence. Classroom teaching is one of the forms of cultural dissemination, and culture has become a force deeply rooted in the hearts of the people, which requires a variety of communication methods, not just classroom teaching to spread Du Fu's own works

Fourth, the mode of cultural communication shows a lag that the new media publicity method is lagging behind and lacking. In view of the principle of confidentiality in military academies, military academies lag far behind local academies in developing new media propaganda. In addition, young officers and soldiers have many restrictions on the use of mobile phones, so the development of new media resources to publicize Du Fu's spirit of benevolence has not yet been tried by military academies.

\section{The Flattening of Cultural Communication Content}

Due to the limitations of the content and time of classroom lectures, in basic courses such as "University Language", Du Fu's poetry is mainly taught, and Du Fu's life experience is briefly introduced. Based on the experience of learning Du Fu's poetry in primary and secondary schools, the cadets of the military academy have a basic and solidified understanding of Du Fu's status as a "poetic saint" and the depressed and frustrated realist poetic style. We retain in our hearts the side of Du Fu who is worried about the country and the people, and who is a pioneer, but he does not have a good understanding of the complexity and profundity of Du Fu's ideological character; there is no comprehensive and profound understanding of why Du Fu became a "poet saint", the mental journey that Du Fu has traveled in his life, Du Fu's noble personality, great ideals, and fraternal mind, and the humanistic spirit of his poetry full of the love of benevolent people. All in all, Du Fu is a cultural celebrity with rich ideological character and diverse personality, and Du Fu's spirit of benevolence has rich connotation and profound educational significance. However, the understanding of military academy cadets is often fixed at one level, and the understanding of Du Fu's work and the spirit of benevolence is relatively superficial, and du Fu's spirit of benevolence, as an important cultural resource of the Chinese nation, has not penetrated well into the cultural construction of military academies, and the inherent rich ideological treasures have yet to be excavated and studied.

In some speech activities and debate competitions, military cadets occasionally quoted Du Fu's poems, but they did not know much about Du Fu's life experience and "Du Fu's poetry contains profound patriotic aspirations, worried thoughts, people-oriented hearts, counterinsurgency wishes, nostalgia" [1], lacked a deep understanding of Du Fu's melancholy character and poetic style, and even thought that this was contrary to the uplifting and positive cultural construction of military academies, and did not have a deep understanding of the importance of Du Fu's benevolent spirit in the military academy. All these are closely related to Du Fu's work and the flattening of the content of the dissemination of the spirit of benevolence. The profoundness and diversity of culture have a multi-angle impact on people, and the value of culture cannot be measured from the perspective of utilitarian usefulness. In the cultural construction of the military campus, $\mathrm{Du} \mathrm{Fu}$ culture and Li Bai culture, Wu Zetian culture, three kingdoms culture in the garrison culture together constitute a rich Bashu culture, anyone living here has the opportunity to hear about such a cultural pattern, so in the dissemination of culture, we strive to avoid flattening, so that it can be integrated into the lives of contemporary people, or that tolerance and acceptance of different cultures is also an attitude towards culture.

\section{Conclusion}

"As a brilliant character in the history of Chinese literature... $\mathrm{Du} \mathrm{Fu}$ was a great Confucian of the Tang Dynasty, who was both a 'sage' in poetry creation and a 'sage' in personality and thought. "Du Fu had a huge influence on China and even the world. However, there are many problems in the construction of Du Fu's benevolent spirit in military academies, which shows that Du Fu's influence in military academies and universities needs to be improved. How to enhance Du Fu's influence, the author will explore the communication strategy of Du Fu's benevolent spirit in military academies in followup research.

\section{Acknowledgment}

This paper is funded by Du Fu Cultural Research Center of Sichuan Department of Education (NO: DFY20189). 


\section{References}

[1] LIU Wei. Poetry Conveys Benevolence: Du Fu's Spiritual Theory of Benevolence[J]. Journal of Jilin Normal University (Humanities and Social Sciences) ,2015,4302:25-29.

[2] Feng Zhi. Du Fuchuan[M]. Beijing: People's Literature Publishing House, 2014:159.
[3] S.Y.Wang.Du Fu, a poet and Confucian -- on the origin of Du Fu's ecological thought [J]. Northern Literature, 2018(27):3839.

[4] [Tang]F.Du.Detailed Notes Of Du's Poem[M].Zhong Hua Book Company, 1979. 